\title{
Mechanism of Haibat Sultan Mountain Landslide in Koya, North Iraq
}

\author{
Sakar A. Sadiq1, Arezh S. Muhmed', Hozan Govar K. Haris', Dastan M. Hamma1, \\ Mohanad M. Abdwllah', Hozan H. Bibani', Hamza K. Muhealddin1, \\ Hawkar A. Mustafa1, Varoujan Sissakian², Nadhir Al-Ansari ${ }^{3}$ \\ ${ }^{1}$ University of Kurdistan, Hawler, Iraq \\ ${ }^{2}$ Pruvate Consultant Einkawa, Erbil, Iraq \\ ${ }^{3}$ Lulea University of Technology, Lulea, Sweden \\ Email: varoujan49@yahoo.com
}

Received 1 August 2016; accepted 22 August 2016; published 25 August 2016

Copyright (C) 2016 by authors and Scientific Research Publishing Inc.

This work is licensed under the Creative Commons Attribution International License (CC BY). http://creativecommons.org/licenses/by/4.0/

(c) (i) Open Access

\section{Abstract}

Haibat Sultan Mountain is a long range with elevation of about $860 \mathrm{~m}$ (a.s.l.); the PilaSpi Formation forms its carapace in Koya vicinity, with relief difference of about $300 \mathrm{~m}$ from Koisanjaq plain. The PilaSpi Formation consists of well thickly to massively bedded dolostone and dolomitic limestone with thickness of about $120 \mathrm{~m}$ in Koya vicinity. The main trend is NW - SE being a limb of Bustana anticline representing part of the southwestern limb, with dip amount that ranges from (15 - 30). On 11th of November 2015 a landslide had occurred after a heavy rainfall along Koya - Dukan main road. The type of the slide was plane sliding due to daylight slope, which was formed after the road cut. The length of the slide area: along the road is $90 \mathrm{~m}$ with height of $40 \mathrm{~m}$ forming almost a parallelogram shape; the thickness of the slid beds is about $2.5 \mathrm{~m}$. The estimated volume of the slid mass is $9000 \mathrm{~m}^{3}$. The main cause of the landslide is the presence of daylight slope, high slope angle; more than the dip angle, presence of old crack surfaces which are filled by reddish brown clayey residual soil. After the he heavy rain fall, which lasted for 20 hours, the infiltrated rain water in the bedding planes in the well bedded, cracked, and jointed beds has increased the pore pressure and decreased the internal friction angle; therefore, the sliding has occurred. The root of the slid mass is below the base of the paved road; therefore, that part which is above the paved road has slid. The remaining part is highly cracked and partly accumulated in the base of the slid mass. Fortunately, the height of the slid mass is only $40 \mathrm{~m}$ and the relief difference between the crown area and the toe area is about $50 \mathrm{~m}$; otherwise the slid mass would be larger than the present slid mass. From the field inspection, it is very clear that the involved area is very unstable and in critical equilibrium. The presence of daylight bedding above the crown area, clayey soil in the fractures and open joints and steep slope all are very favorable conditions for triggering the unstable slope, consequently developing of another landslide with larger mass. 


\section{Keywords}

\section{Landslide, Plane Slide, Shear Plane, Daylight Slopes, Iraq}

\section{Introduction}

On the 11th of November 2015, a landslide had occurred after a heavy rainfall along Koya - Dukan main road, north Iraq, Kurdistan Region, and it will be called Koya Landslide in the current study. The sliding had happened due to daylight slope, which was formed after the road cut. The main road was blocked by the slid mass for overnight.

The studied area is located northeast of Koisanjaq town, along the main road between Koisanjaq town and Sulaimaniyah city via Dukan town (Figure 1). It is a mountainous area, located along the southwestern flank of Haibat Sultan Mountain with elevation of about $860 \mathrm{~m}$ with relief difference with the center of Koisanjaq town of about $300 \mathrm{~m}$.

The main aim of this study is to record the landslide event and describe the details of the slid mass and other parts of the landslide with investigating and discussing the reasons of the sliding. Moreover, to recommend relevant preventative actions that should be considered in order not to trigger the involved area, this is in very critical equilibrium states.

\subsection{Previous Studies}

Studies concerning the study area are very rare; however, as general mass movements studies are concerned;

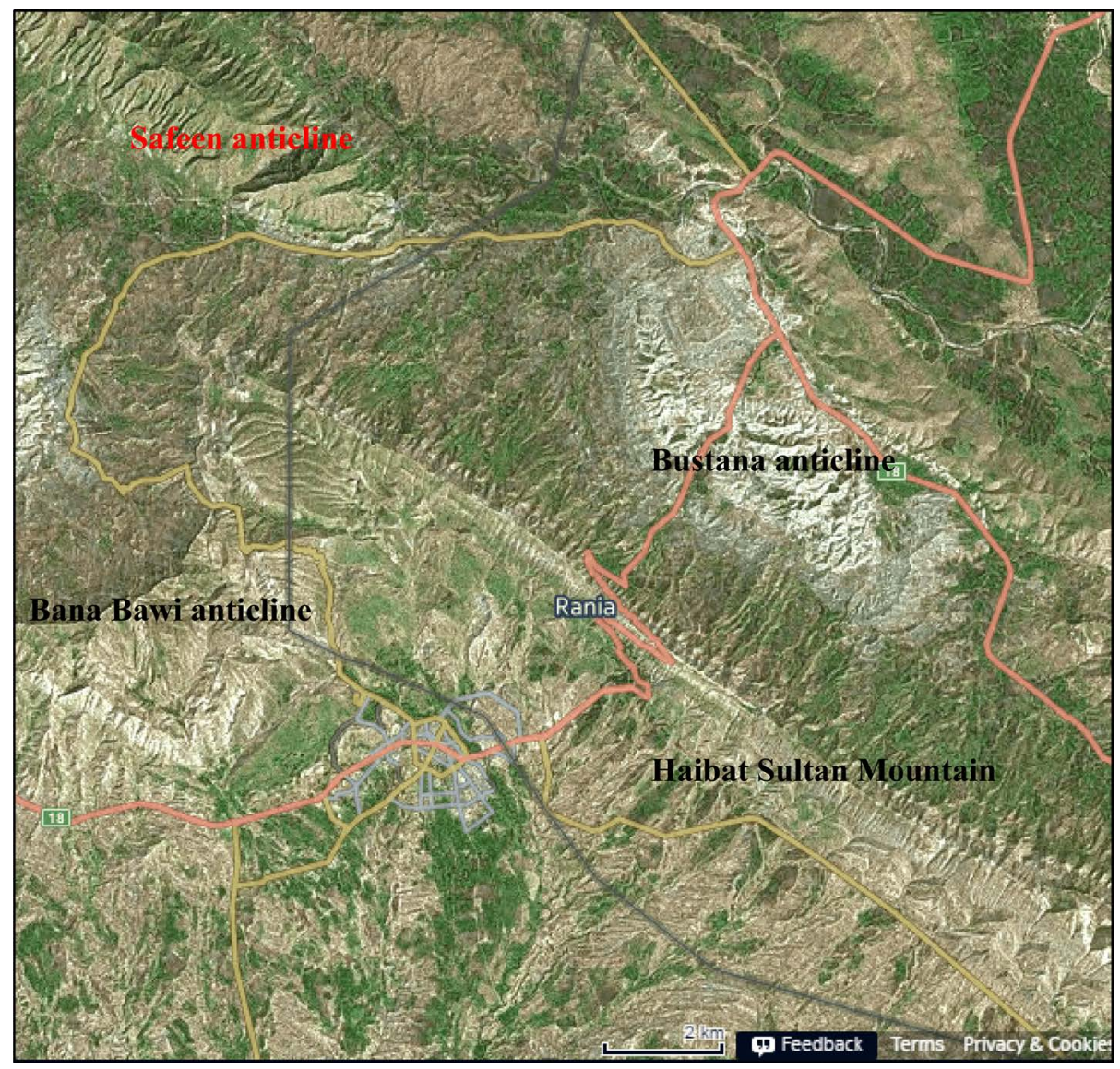

Figure 1. Falsh earth image of the studied area. 
few are present. Generally, regional studies are available; not for individual events; hereinafter are some of those studies.

Sissakian and Ibrahim [1] conducted a geological hazards study of the whole Iraqi territory and considered the area of Koya Landslide as Active Mass Movement zone.

Sissakian and Ibrahim [2] compiled the Geological Hazards Map of Iraq and considered the area of Koya Landslide as Unstable Mass Movements Zone.

Sissakian and Ibrahim [3] compiled the Geological Hazards Map of Erbil - Mahabad Quadrangle at scale of 1:250,000 and presented the landslide area on the map as unstable area.

\subsection{Materials and Methods}

In order to achieve the main aim of this study, which is to describe and discuss the reasons of Koya Landslide, the following materials were used:

- Topographic and geological maps of different scales.

- Google Earth and FLASH Earth images.

- Different geological published articles and reports.

- Historical books.

- Field observation data.

Using the available topographical and geological maps of different scales with the help of FLASH Earth and Google Earth images, the location of Koya Landslide is determined and the stability of the area and near surroundings is evaluated. The parameters of the landslide were measured during a field work that was carried out on the second day of the event. The exact limits of the landslide were mapped, significant parameters of the landslide; such as crown area, shear plane, dimensions were measured and documented by tens of photos.

\section{Geological Setting}

The geomorphology, structural geology and tectonics, and stratigraphy of the study area are given briefly; hereinafter, depending mainly on best available data [4]-[7].

\subsection{Geomorphology}

The main geomorphological units in the studied area are:

- Anticlinal ridges: The thickly well bedded massive carbonates of the PilaSpi Formation have formed obvious anticlinal ridges along the southwestern limb of Bustana, BanaBawi and Khalikan anticlines

- Alluvial fans: Many small alluvial fans are developed in the study area and near surroundings, especially when the valleys cross the PilaSpi Formation towards the Gercus Formation.

- Flat irons: These are well developed due to the thickly well bedded and massive carbonates of the PilaSpi Formation (Figure 1). Their height and widths range from (50 - 150) $\mathrm{m}$ and $(25-150) \mathrm{m}$, respectively.

- Mass movements: Many small phenomena occur in the study area, like toppling, mud flows, landslides and rock fall.

\subsection{Structural Geology and Tectonics}

The study area is located on the southwestern limb of Bustana anticline, which is an NW - SE trending double plunging anticline. The length is about $11 \mathrm{Km}$, whereas the width is about $3.5 \mathrm{Km}$. The southern limb is steep; up to $55 \mathrm{Km}$, whereas the northeastern limb is very gentle; not more than $20 \mathrm{Km}$ (Figure 1). Moreover, BaniBawi and Safeen anticlines have direct effect on the folding style and dipping of the beds in the study area (Figure 1).

Tectonically, the studied area is located within the High Folded Zone of the Outer Platform (Unstable Shelf) of the Arabian Plate [6]. The zone is characterized by narrow and long anticlines with wide and shallow synclines. Some of the anticlines exhibit thrust faulting; where the northeastern limb is thrusted over the southwestern one or the northern limb is thrusted over the southern one.

\subsection{Stratigraphy}

In the study area, only the PilaSpi Formation is exposed; however, the overlying and underlying formations are described hereinafter; briefly depending on best available data [3]-[5] [7]. 
- Gercus Formation: The formation consists of red clastics; mainly claystone and sandstone with some fine conglomerate. The presence of thick claystone beds may form slippery plain for sliding.

- PilaSpi Formation: The formation consists of thickly well bedded carbonates; dolomite, dolomitic limestone with rare marl and marly limestone beds in the lowermost part of the formation.

- Fatha Formation: The formation, in the study area consists of thickly bedded claystone, siltstone with very rare limestone and gypsum in cyclic nature.

\section{Koya Lanslide}

\subsection{General}

At the night of 11th of November 2015 a landslide (Figure 2) had occurred after a heavy rainfall that lasted for about 20 hours along Koya - Dukan main road that was constructed in 1976 but was widened many times leaving steep daylight slopes along the road (Figure 3).

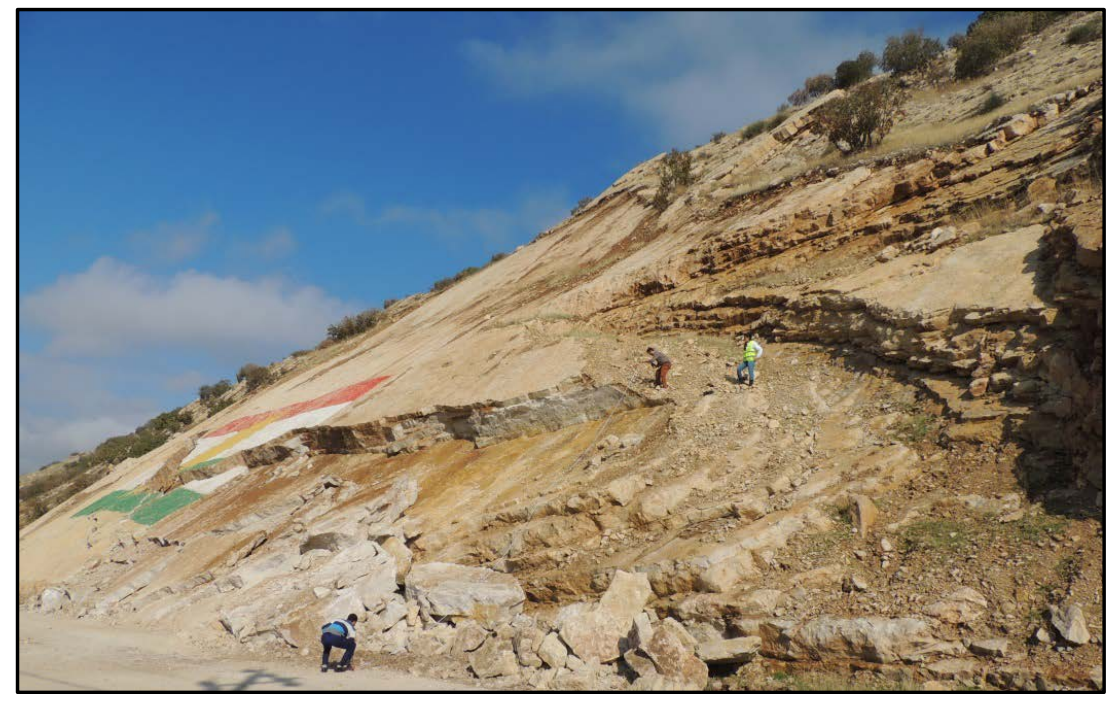

Figure 2. General view of Koya Landslide (the slid mass is removed).



Figure 3. Part of Koya Lnadslide, note the old daylight slopes (ODS) formed due to the road cut and the recently formed daylight slope (RDS) due to the landslide. 


\subsection{Geometry of Koya Landslide}

The length of Koya Landslide area; along the road is $90 \mathrm{~m}$ with height of $40 \mathrm{~m}$ forming almost a parallelogram shape (Figure 2); the thickness of the slid beds is about $2.5 \mathrm{~m}$ (Figure 4). The estimated volume of the slid mass is about $9000 \mathrm{~m}^{3}$.

\subsection{Type of Koya Landslide}

Koya Landlside is a rock bedding slide that had happened along the bedding plane of the well bedded carbonates of the PilaSpi Formation (Figures 2-4). Two and locally three bedding planes are acted as sliding plain.

\subsection{Crown Area}

The crown area of Koya Landslide has not a continuous arch form (Figure 5) as it is usually in landslides [8]. This is attributed to the presence of old daylight slopes that have previously acted as crown area; therefore, the crown of the recent landslide is almost joined with the old forming irregular cliff of the crown area.

\subsection{Shear Plane}

The shear plane of Koya Landlside is very clear (Figures 3-5); since the landslide is of a plane slide type. The

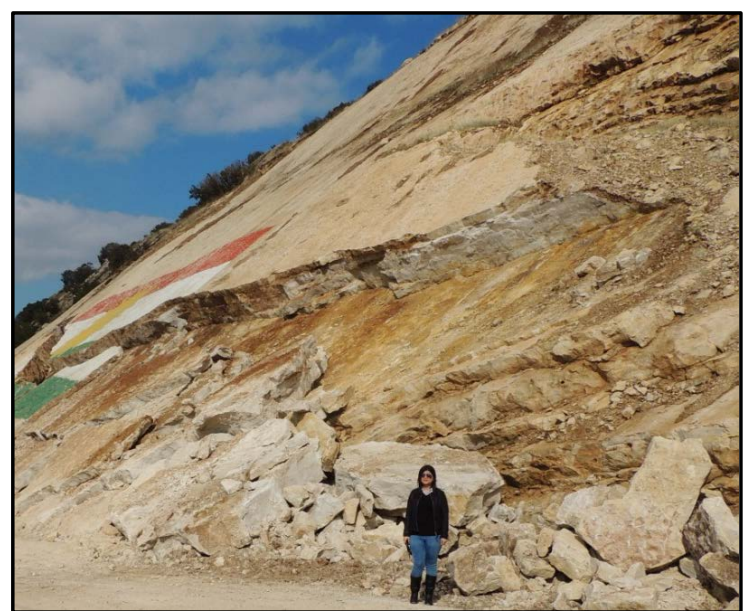

(a)

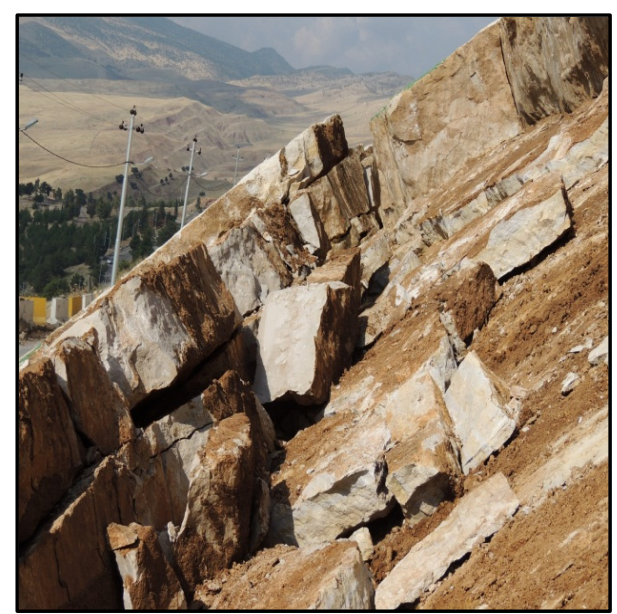

(b)

Figure 4. Koya Landslide, (a) Recently formed daylight slope and thickness of the slid blocks, (b) Thickness of the slid blocks.

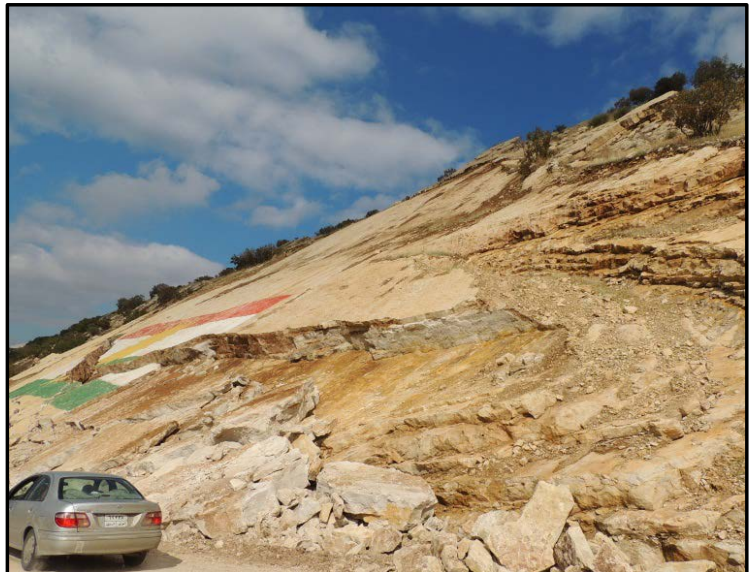

(a)

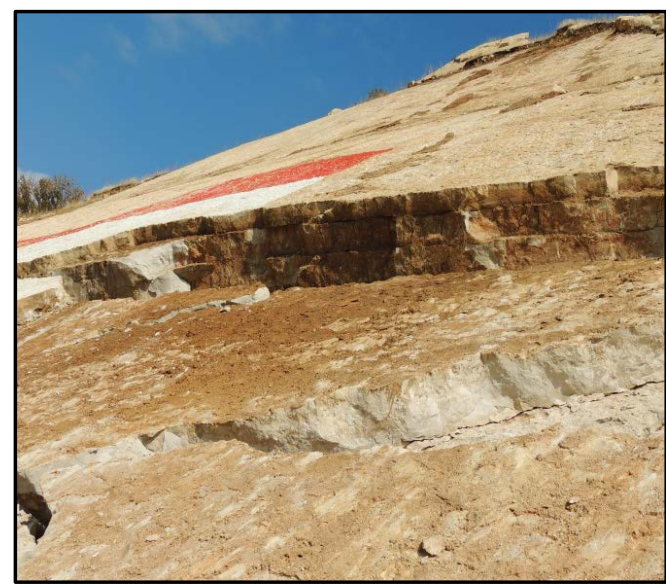

(b)

Figure 5. Koya Landslide, (a) The crown area, note the presence of a crown of an old landslide, (b) Details of the shear plane. 
shearing traces are very clear along the bedding planes of the slid mass as vertical grooves formed parallel to the dip direction, which is the same of sliding direction.

\subsection{Toe Area}

The toe area of Koya Landslide was removed in the second day of the sliding; since it was bocked the main road between Koisanjaq and Dukan towns. It was in form of accumulated blocks on the paved road (Figure 6(a)), locally mixed with blocks of the paved road that was damaged and cracked into blocks due to the sliding (Figure 6(b)).

\section{Causes of Koya Landslide}

In Koya Landslide, multiple types of causes had developed the landslides these are explained hereinafter.

\subsection{Geological Causes}

Among these causes are the presences of well bedded carbonates encountered rarely with marl horizons (Figure $7(a))$ and weathered materials in form of reddish brown clayey soil that was filling the cracks and opened bedding planes (Figure 7(b)). Moreover, the presence of joints, well bedded; locally thinly bedding planes and fractures, all have acted as weakness zones, besides being good passage for the rain water in between the bed-

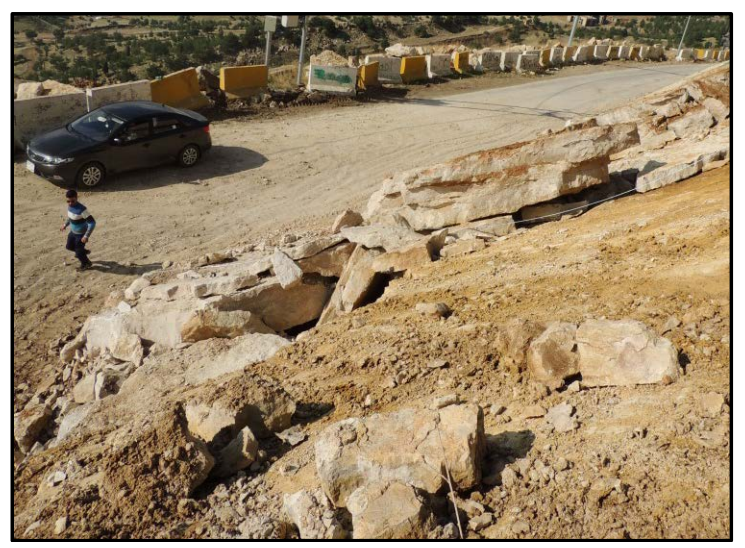

(a)

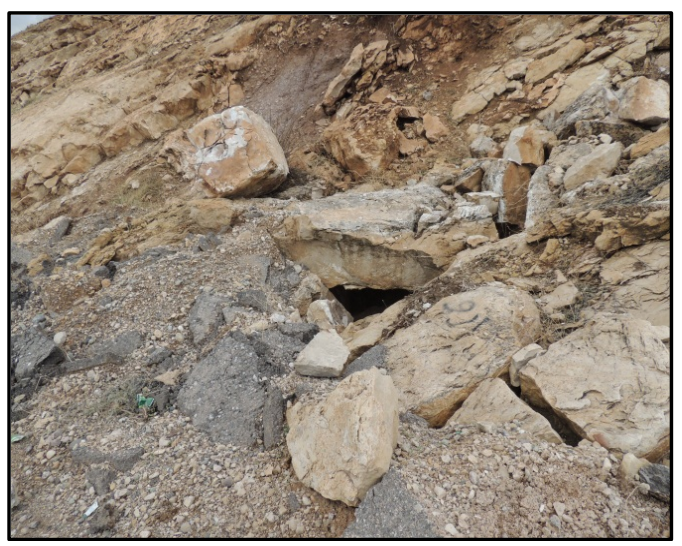

(b)

Figure 6. Toe area of Koya Landslide, (a) The remains of the toe area, (b) Blocks of the toe area impregnated in the paved road.

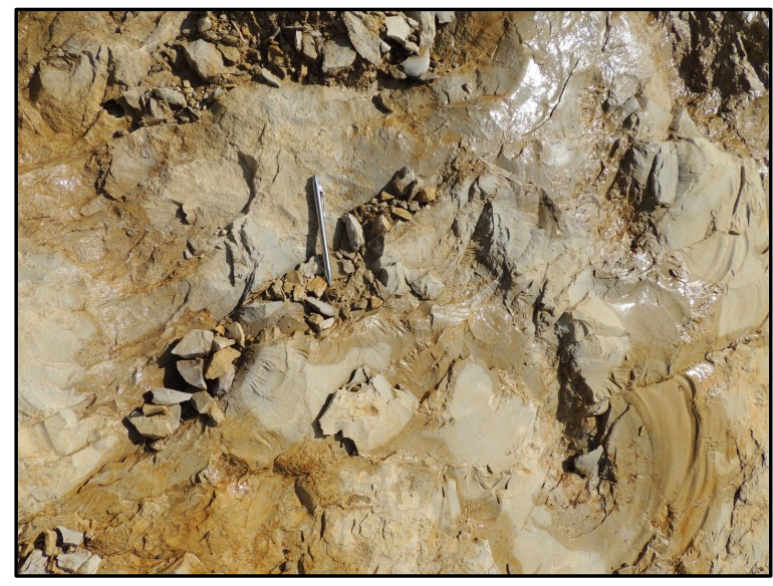

(a)

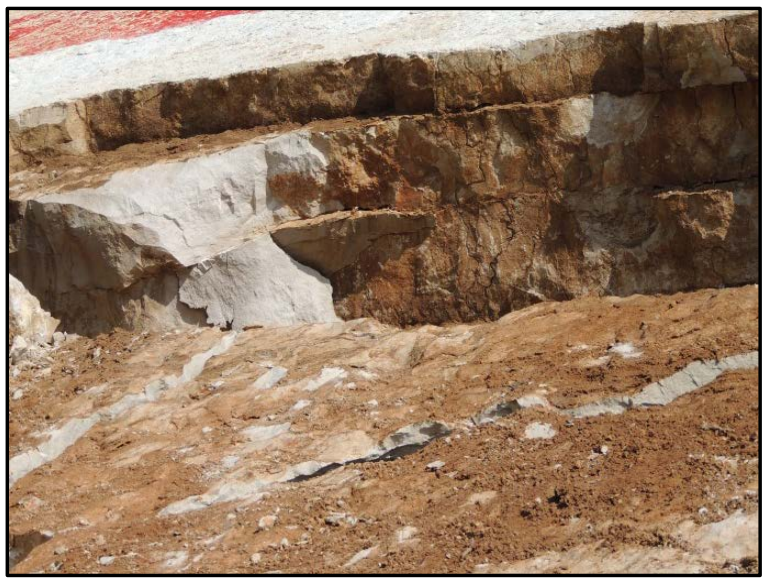

(b)

Figure 7. (a) Olive green marl encountered with the well bedded carbonates of the PilaSpi Formation, (b) Reddish brown clayey soil filling the cracks, bedding planes, fissured. Contrast in permeability and/or stiffness of materials. 
ding planes.

\subsection{Morphological Causes}

Among morphological causes, the main one is the fluvial erosion by the rain water, besides the freeze-and-thaw weathering and shrink-and-swell weathering that have acted after continuous raining for 20 hours and drop in daily temperatures during November where the temperature may fall to zero and even below.

Moreover, the heavy rain shower and the presence of open cracks, fishers, joints; all filled with clay, may had caused formation of piping phenomenon by means of which the formed slurry in the opened voids has triggered and accelerated the sliding; acting as lubricant agent.

\subsection{Human Causes}

Among the human causes, the excavation and blasting of the rocks during widening of the road had formed fishers and cracks in the well bedded carbonates of the PilaSpi Formation (Figure 8). Moreover, the slide area and near surroundings are free of natural vegetation, whereas, there are dense trees and shrubs in the upper part (Figure 8).

The narrow one lain paved road with very steep gradient, also may acted as artificial vibration due to the passage of heavy trucks along the road. Such vibration also may trigger and accelerate the sliding [8]-[10].

\section{Precaution and Landslide Control}

As in each mass movement phenomenon, Koya Landslide area is a prone area for different types of mass movements, especially landslide, toppling and rock fall (Figure 9(a)). Therefore, even traffic sign (Figure 9(b)) is fixed in the involved area indicating unstable slope and to pay attention of the drivers along the one lane road. Moreover, in the landslide area, there was an old landslide (Figure 10) and still is suffering from unstable slopes. It is worth mentioning that in each old landslide area, new mass movements are expected [8]-[11].

For each type of mass movement, there are certain types of precautions to control the movement [8]. In Koya Landslide, since it is of bedding slide type, the strike of the beds is parallel to the road, presence of daylight slope due to steep road cut and some of the beds are intensely jointed, fractured and thinly bedded (Figure 3, Figure 5 and Figure 8); therefore, the most reliable processes to control and stabilize the unstable slope and to prevent repetition of the sliding in the future, the following steps should be considered:

1) Digging a ditch surrounding the upper part of the landslide and near surroundings (Figure 10) and lining the ditch by concrete to prevent infiltration of the rainfall water to the slide area and near surroundings.
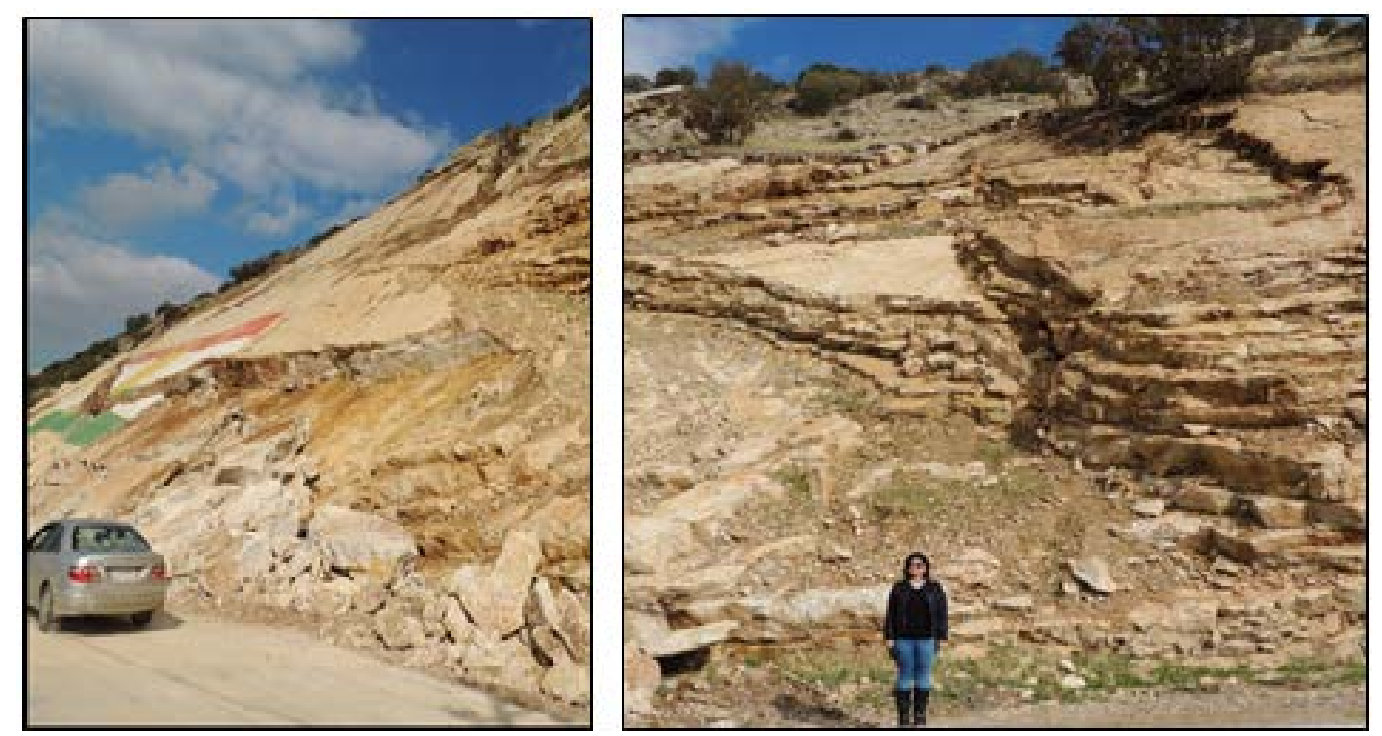

Figure 8. Koya Landslide, note the well bedded, jointed, fractured and fissured carbonates of the PilaSpi Formation. Also note the absence of the vegetation in the slide area. 


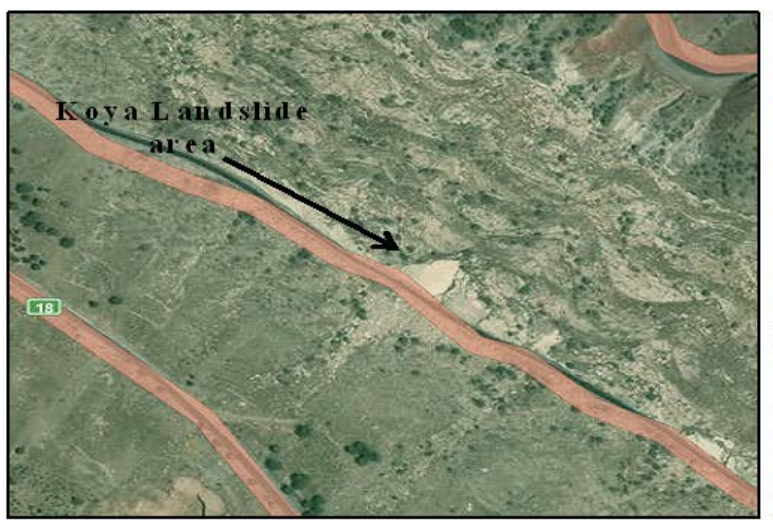

(a)

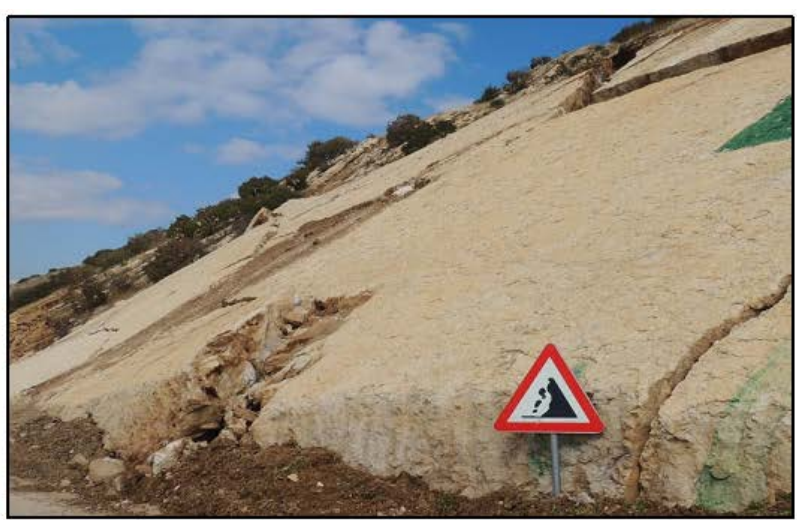

(b)

Figure 9. (a) Flash Earth image showing Koya Landslide area, (b) Traffic sign indicating unstable slope.

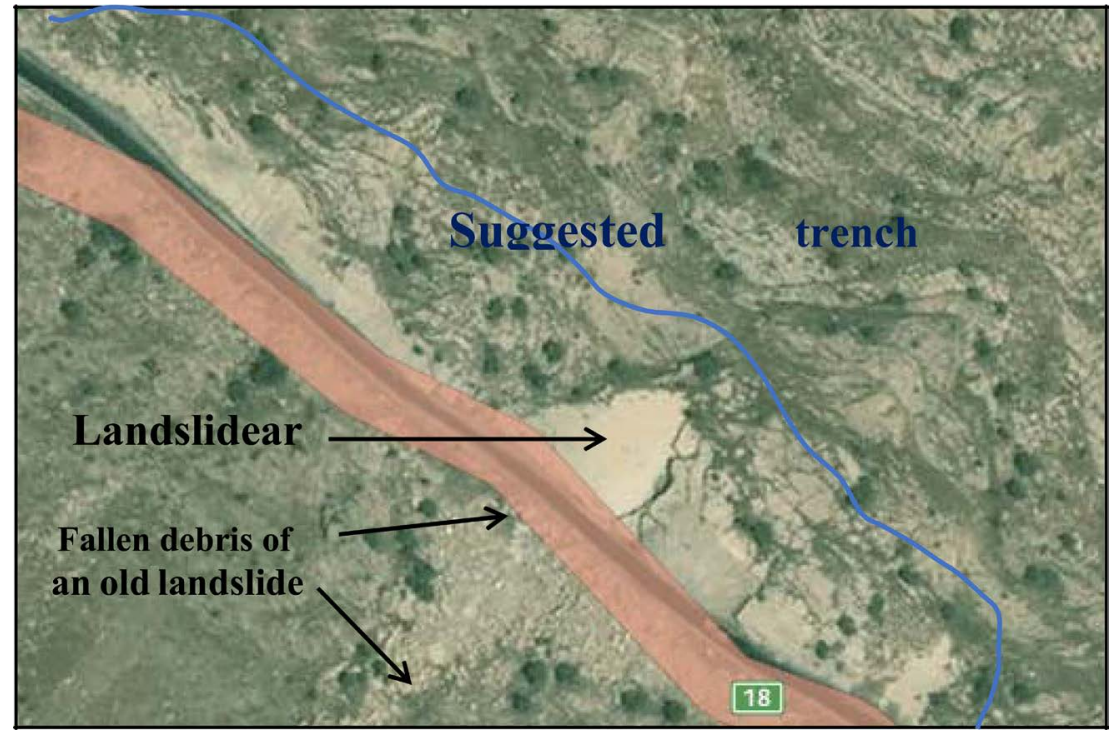

Figure 10. Here Maps image of Koya Landslide area showing the suggested.

2) Decreasing the slope of the daylight slopes initiated by haphazard cutting of the slope during widening of the road.

3) Bolting and anchoring the massive carbonate beds (Figures 2-5). After performing special study to choose the proper length of the anchors and/ or bolts, intensity of the anchoring; including the distance between them, angle of the anchoring and location of the anchors [12].

4) Increasing the vegetation on the upper limits of the landslide area and near surroundings.

5) Construction of relevant concrete protection wall [10].

\section{Discussion}

Slope saturation by water is a primary cause of landslides. This effect had occurred in Koya Landslide form intense rainfall, where there is a distinct zone of weakness that separates the slide material from more stable underlying material (Figure 11(a)). The infiltrated rain water has increased the pore water pressure and consequently decreased the internal friction angle [13]; therefore, the mass above the weakness zone has received more forces to move downslope and because the internal friction angle was reduced; therefore, the mass was separated from the bulk mass of the mountain and moved down slope freely, but for a limited distance.

The presence of clayey materials in between the open joint and bedding planes, and previously existing fractures (Figure 7(b) and Figure 11(b)), has accelerated the sliding and formed a slippery plain. The reddish 


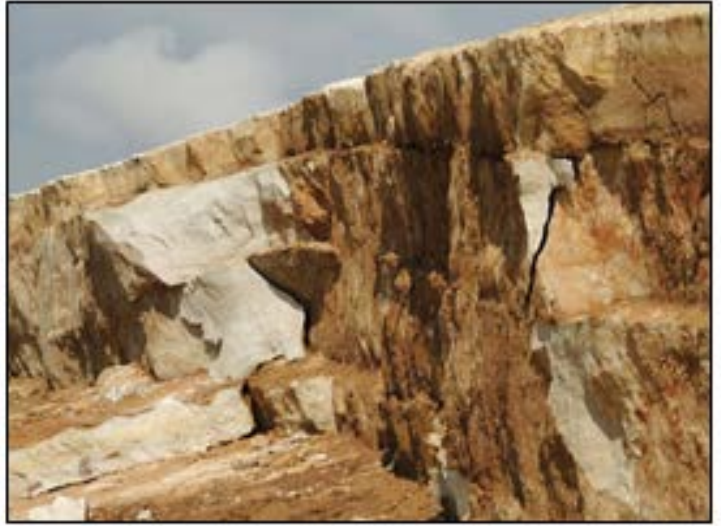

(a)

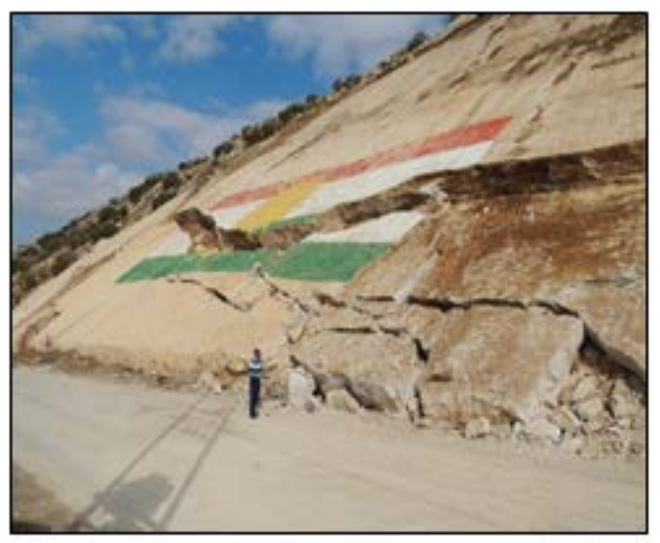

(b)

Figure 11. Part of Koya Landslide. (a) Note the recently occurred surface due to sliding and compare it with previously occurring separated surface. (b) The lowermost part of the slide.

brown clayey materials were formed as residual soil due to the weathering of the carbonates of the PilaSpi Formation.

The location of the Koya Landslide was suffering from slope stability problems. An old landslide and active rock fall (Figure 10) confirm the presence of unstable slope, which was easily, triggered forming the new landslide. Such cases are well known all over the world [7]-[11].

The height difference between the crown area and the toe area is only $40 \mathrm{~m}$; therefore, the landslide area is a small one. This is attributed to the fact that the bedding plane along which the slide has occurred; terminates just with the paved road (Figure 6), which has played the role of retarding the downslide forces and the speed, because the beds were excavated during the road cut and the flat area on top of which the road was constructed has played as a supporter to the slid mass (Figure 11(b)).

\section{Conclusions}

The following can be concluded from the current study:

The Koya Landslide is a block-plane slide of translational slide type in which the moving mass consists of a single unit that gas moves downslope as a relatively coherent mass.

The main cause of the landslide is the rain water: after the heavy rain showers on the date of the sliding that has increased the pore water pressure and decreased the internal friction angle.

The previously existing unstable slope: due to the presence of old landslide and rock fall phenomena in the involved slide area.

The presence of daylight slopes due to haphazard cutting of the slope during the road cut and road widening has accelerated and triggered the sliding.

The absence of the vegetation also has played a significant role in the sliding.

The presence of clayey materials between the bedding planes, open joint planes and fractures has played as slippery plain after being oversaturated by the rain water.

\section{References}

[1] Sissakian, V.K. and Ibrahim, F.A. (2002) Zonation of Geohazards in Iraq. Iraq Geological Survey Library Report No. 2757, Baghdad, Iraq, 19 p.

[2] Sissakian, V.K. and Ibrahim, F.A. (2005) Series of Geological Maps of Iraq, Geological Hazards Map of Iraq, Scale 1: 1,000,000. Iraq Geological Survey Publications, Baghdad.

[3] Sissakian, V.K. and Ibrahim, F.A. (2004) Series of Geological Hazard Maps of Iraq, Erbil and Mahabad Quadrangles, Scale 1:250,000. Iraq Geological Survey Library Report No. 2004.

[4] Sissakian, V.K. and Youkhanna, R.Y. (1979) Report on Regional Geological Mapping of Erbil-Shaqlawa-Koi SanjaqRaidar Area. Iraq Geological Survey Library Report No. 2004.

[5] Sissakian, V.K. and Fouad, S.F. (2012) Geological Maps of Iraq; Scale 1: 1,000,000. 4th Edition, Iraq Geological Sur- 
vey Publications, Baghdad.

[6] Fouad, S.F. (2012) Tectonic Maps of Iraq; Scale 1: 1,000,000. 3rd Edition, Iraq Geological Survey Publications, Baghdad.

[7] Sissakian, V.K. and Saeed, Z.B. (2012) Lithological Map of Iraq, Compiled Using GIS Techniques. Iraqi Bulletin of Geology and Mining, 8, 1-13.

[8] Varnes, D.J. (1978) Slope Movement Types and Processes. In: Schuster, R.L. and Krizek, R.J., Eds., Landslides, Analysis and Control, Transportation Research Board, Special Report No. 176, National Academy of Sciences, 11-33.

[9] Cruden, D.M. and Varnes, D.J. (1996) Landslide Types and Processes. In: Turner, A.K. and Shuster, R.L., Eds., Landslides: Investigation and Mitigation, Transportation Research Board, Special Report No. 247, 36-75.

[10] Tokmechi, Z. (2011) Landslide Mitigation and Its Risk Controlling. American-Eurasian Journal, Agriculture and Environment Science, 10, 49-54.

[11] USGS (2016) Landslide Preparedness. Landslide Hazards Program, Landslide.

[12] Turner, J., Johnon, L. and Boundy, B. (2002) Performance of Permanent Ground Anchors for Landslide Stabilization. Batter Highways through Applied Geology, 53rd Annual Highway Geology Symposium. The National Academy of Science, Engineering and Medicine, California.

[13] Terzaghi, K. and Peck, R.B. (1948) Soil Mechanics in Engineering Practice. John Wiley \& Sons, Hoboken.

\section{Submit or recommend next manuscript to SCIRP and we will provide best service for you:}

Accepting pre-submission inquiries through Email, Facebook, LinkedIn, Twitter, etc.

A wide selection of journals (inclusive of 9 subjects, more than 200 journals)

Providing 24-hour high-quality service

User-friendly online submission system

Fair and swift peer-review system

Efficient typesetting and proofreading procedure

Display of the result of downloads and visits, as well as the number of cited articles

Maximum dissemination of your research work

Submit your manuscript at: http://papersubmission.scirp.org/ 